\title{
Type 2 Diabetes Mellitus can be Prevented in Tobacco Shop Workers
}

\author{
Mercedes Fusté Bruzain ${ }^{1 *}$, Yamila Roque Doval² and Roberto Rodríguez González² \\ ${ }^{1}$ Twisted Base Business Unit. Camajuaní, Villa Clara. Cuba \\ ${ }^{2}$ Central University Marta Abreu de las Villas. Cuba
}

*Corresponding author: Mercedes Fusté Bruzain, Twisted Base Business Unit, Camajuaní, Villa Clara, Cuba

\section{ARTICLE INFO}

Received: 幽 November 19, 2019

Published: 慧 November 26, 2019

Citation: Mercedes Fusté Bruzain, Yamila Roque Doval, Roberto Rodríguez González. Type 2 Diabetes Mellitus can be Prevented in Tobacco Shop Workers. Biomed J Sci \& Tech Res 23(2)-2019. BJSTR. MS.ID.003872.

Keywords: Type 2 diabetes mellitus, morbidity and mortality

\begin{abstract}
The control of type 2 diabetes mellitus should be early and regular to prevent chronic complications and it represents a current global health problem. A descriptive observational study was conducted with 23 workers who present this condition in the cigar Factory of Camajuaní from January to September 2019, with the aim of preventing chronic complications in this type of patient. $70 \%$ of the diagnoses were made by blood glucose while fasting. The presence of chronic complications and concomitant diseases was detected, such as: Diabetic polyneuropathies, skin diseases and non-alcoholic steatohepatitis. It was detected by examinations indicated to check the health of the workers and a late diagnosis was made, in the presence of chronic complications. The need for prevention and health promotion work was evidenced by the factory reader, in order to avoid morbidity and expansion rates in workers.
\end{abstract}

Background: Type 2 diabetes mellitus, prevention is one of the lines of the staff in the cigar factory of Camajuaní.

Objective: To prevent type 2 diabetes mellitus in the cigar factory workers of the municipality of Camajuaní Cuba.

Methods: The investigation covered a period from January to September 2019; A descriptive observational study was carried out in the cigar factory of Camajuaní, where there was a sample of 23 with symptoms of the disease out of a population of 60 tobacco users.

Results: The presence of chronic complications and concomitant diseases was detected, such as: Diabetic polyneuropathies, skin diseases and non-alcoholic steatohepatitis. It was detected by examinations indicated to check the health of the workers and a late diagnosis was made, in the presence of chronic complications. Through the tobacco reader, health prevention and promotion actions are carried out.

Conclusion: It is evident and urgent the need to increase the work of prevention and health promotion, through the different educational means that Cuba has, in order to avoid the high morbidity and expansion rates of this disease, and to promote a more committed attitude of health personnel at the primary level. Through the Factory reader, health prevention and promotion actions are carried out.

\section{Short Communication}

Chronic complications of diabetes mellitus are one of the leading causes of disability, death and high costs in medical care. Different methods can be used to evaluate the late complications of the disease, highlighting the prevalence rate in the short or long term. Another useful indicator is the prevalence by years of evolution [1]. Nowadays, diabetes mellitus (DM) is considered the most common endocrine disorder (it affects 2 to $6 \%$ of the world population and represents one of the biggest health problems 
because it significantly increases morbidity and mortality rates [2]. The countries with the largest number of people with diabetes are mostly in Western Europe, such as Germany, Spain, Italy, Greece and the United Kingdom [3]. According to the International Diabetes Federation (a disease that is currently considered a pandemic) there are 415 million diabetics, of which three quarters live in low- and middle-income countries. By 2040, this figure is expected to increase to 642 million in the planet; and specifically, in Latin America, a prevalence of $5.7 \%$ is estimated [4]. According to data from the 2017 statistical yearbook in Cuba, [5] the DM represented in 2015 and 2016 the eighth cause of death. Not only does it constitute one of the main causes of death itself, but it is a major risk factor for cardiovascular diseases (the leading cause of death in Cuba) [6].

\section{Materials and Methods}

The study is classified as descriptive observational, belonging to the quantitative research methodology. With the aim of preventing type 2 diabetes mellitus in the workers of the cigar factory of the municipality of Camajuaní Cuba. To obtain results, methods at the theoretical and empirical levels are used [7]. At the theoretical level the analytical-synthetic, historical-logical, systemic-structural and inductive-deductive are used. At the empirical level, the classic documentary analysis, the survey, psychological observation, mathematical statistical method is used. As techniques were used the questionnaire, interview, triangulation of information and percentage analysis with the support of SPSS software and the help of descriptive statistics. Statistical processing allows analogies to be established between the results obtained and the scientific literature published around Type 2 Diabetes mellitus. The sample consists of 23 workers from the cigar factory of Camajuaní Cuba.

The inclusion criteria were:

1) Workers without cognitive impairments

2) Desire to participate in the investigation

3) Both genders

The exclusion criteria were:

1) Workers with cognitive impairments

2) Those who express wishes not to participate in the investigation

\section{Exit Criteria:}

1. Workers who voluntarily abandon research

2. The following variables were used based on the data obtained: age, sex. Authorization was requested from the workers of the cigar factory in Camajuaní.

\section{Developing}

The cigar Factory of the municipality of Camajuaní is a social institution. It is in the urban center of the City. It opens from Monday to Friday for a week and another from Monday to Saturday with various activities that allow workers to socialize with each other (Table 1). All workers have knowledge of diabetes as a disease and that in Cuba it represents a health problem for people, but they do not know its symptoms. $47.83 \%$ of workers have weight loss, sometimes most of these symptoms of diabetes are not recognized by them which leads to a late diagnosis of the disease and there can be several complications (Table 2). The presence of chronic complications and concomitant diseases was detected, such as: Diabetic polyneuropathies in seven workers, skin diseases in eleven workers and non-alcoholic steatohepatitis in five. It was detected by examinations indicated to check the health of the workers and a late diagnosis was made, in the presence of chronic complications. Through the factory reader, health prevention and promotion actions are carried out.

Table 1: Distribution of the cigar factory workers of Camajuaní (Source: self elaboration).

\begin{tabular}{|c|c|c|c|c|c|c|}
\hline \multirow{2}{*}{$\begin{array}{c}\text { AGE } \\
\text { (Years) }\end{array}$} & \multicolumn{4}{|c|}{ Sex } & \multirow{2}{*}{ TOTAL } & \multirow{2}{*}{$\%$} \\
\hline & Female & $\%$ & Male & $\%$ & & \\
\hline $25-35$ & 3 & 13.04 & 3 & 13.04 & 6 & 26.09 \\
\hline $35-45$ & 8 & 34.78 & 3 & 13.04 & 11 & 47.82 \\
\hline $45-50$ & 4 & 17.39 & 2 & 8.70 & 6 & 26.09 \\
\hline TOTAL & 15 & 65.21 & 8 & 34.78 & 23 & 100.0 \\
\hline
\end{tabular}

Table 2: Diabetes knowledge(Source: self made).

\begin{tabular}{|c|c|c|}
\hline Knowledge of Diabetes as a Disease & workers & \% \\
\hline They know & 23 & 100.0 \\
\hline $\begin{array}{c}\text { They don't know } \\
\text { Their symptoms }\end{array}$ & 0 & 0 \\
\hline Total & $\mathbf{2 3}$ & $\mathbf{1 0 0 . 0}$ \\
\hline
\end{tabular}

1. To inform workers of the main symptoms of diabetes mellitus,

2. To keep blood pressure below $130 / 80 \mathrm{mmHg}$,

3. To avoid smoking,

4. The control of pre-prandial and postprandial glycemia in people,

5. Periodically check the weight

\section{Conclusion}

It is evident and urgent the need to increase the work of prevention and health promotion, through the different educational means that Cuba has, in order to avoid the high morbidity and expansion rates of this disease, and to promote a more committed attitude by health personnel at the primary level (Table 3). Through the factory reader, health prevention and promotion actions are carried out. The prevention of associated risk factors (smoking, obesity, high blood pressure and dyslipidemia) and early diagnosis prevent the early onset of chronic complications (Table 4). The control of pre-prandial and postprandial glycemia in people, elimi- 
nating smoking habits, periodically controlling weight, maintaining blood pressure below 130/80 mmHg and practicing physical exercise on a regular basis allow people to keep a healthy life.

Table 3: Main symptoms(Source: self made).

\begin{tabular}{|c|c|c|}
\hline Principales Síntomas & Trabajadores & \% \\
\hline Poliuria & 1 & 4.34 \\
\hline Polidipsia & 4 & 17.39 \\
\hline Polifagia & 7 & 30.44 \\
\hline Weight loss & 11 & 47.83 \\
\hline Total & $\mathbf{2 3}$ & $\mathbf{1 0 0 . 0}$ \\
\hline
\end{tabular}

Table 4: Chronic complication(Source: self made).

\begin{tabular}{|c|c|c|}
\hline Chronic complications & workers & $\mathbf{\%}$ \\
\hline Diabetic polyneuropathies, & 7 & 30.44 \\
\hline Skin diseases & 11 & 47.83 \\
\hline $\begin{array}{c}\text { non } \\
\text { alcoholic } \\
\text { Steatohepatitis }\end{array}$ & 5 & 21.73 \\
\hline Total & $\mathbf{2 3}$ & $\mathbf{1 0 0 . 0}$ \\
\hline
\end{tabular}

ISSN: 2574-1241

DOI: $10.26717 /$ BJSTR.2019.23.003872

Mercedes Fusté Bruzain. Biomed J Sci \& Tech Res

(c) 7 This work is licensed under Creative

Submission Link: https://biomedres.us/submit-manuscript.php

\section{References}

1. Krolewski AS, Warren JH, Freire BS (1996) Chronic complications of diabetes. Epidemiology or late diabetic complications. Endocrinol Metabol Clin North Am 25(2): 217-242.

2. Botas Velasco M, Cervell Rodríguez D, Montalbán AR, Jiménez SV, De Valderrama Martínez IF, et al. (2017) Actualización en el diagnóstico, tratamiento y prevención de la neuropatía diabética periférica. Angiología 69(3): 174-181

3. Federación Internacioanl de Diabetes, Atlas de la diabetes, (6 $6^{\underline{a}}$ Edn.).

4. Rydén L, Grant PJ, Anker SD, Berne C, Cosentino F, et al. (2014) Guía de práctica clínica de la ESC sobre diabetes, prediabetes y enfermedad cardiovascular, en colaboración con la European Association for the Study of Diabetes. Rev Esp Cardiol 67(2).

5. (2017) Cuba. Ministerio de Salud Pública. Anuario Estadístico de Salud. La Habana: Dirección de Registros Médicos y Estadísticas de Salud.

6. Escribano Serrano J, Michán Doña A, Glucohemoglobina A1c (2013) Diabetes Práct.

7. González Tabares R, Aldama Leonard IY, Fernández Martínez L, Ponce Baños I, Rivero Hernández MC, et al. (2015) Hemoglobina glucosilada para el diagnóstico de diabetes mellitus en exámenes médicos preventivos. Rev Cubana Med Mil 44(1).

$\begin{array}{ll}\text { BIOMEDICAL } & \text { Assets of Publishing with us } \\ \text { RESEARCHES } & \text { - Global archiving of articles } \\ \text { - Immediate, unrestricted online access } & \text { - Rigorous Peer Review Process } \\ & \text { - Authors Retain Copyrights } \\ \end{array}$

